\title{
Protecting the interests of the group (collective) in the jurisdiction of courts of common pleas and the Supreme Court in Poland
}

\begin{abstract}
The Act of 17 December 2009 on pursuing claims in class actions regulating court proceedings in cases which involve claims of at least 10 people, is a kind of novelty in Polish law. Undoubtedly, it is a legal act improving and modernizing Polish civil proceedings. However, one should pay attention to new developments and the lack of their clarification, and therefore to the importance of already issued judgments of the Supreme Court. For this reason, existing jurisdiction on this subject has been presented and analyzed, which allows to precise the subjective scope, the term and extent of the unification of claims, as well as the concept and requirement of a representative of the collective. Without any doubts, the practice, which starts to shape, as indicated on the example of jurisdiction, will allow to clarify the scope of the subject and object of the Act. The ability to limit the claims for liability of the defendant has, without any doubts, a very important role in functioning of the class action, because the unification of pecuniary claims is in practice very difficult. Past court decisions show that unification should be understood as occurrence of a members' request for the generically same forms of protection. Many practical problems are also raised by the concept of the representative of the collective, and the way, in which the collective should choose one.
\end{abstract}

Keywords: representative of the collective, class action, unification of claims, consument

1 Dr Joanna Maria Studzińska - adiunkt w Katedrze Postępowania Cywilnego Katolickiego Uniwersytetu Lubelskiego Jana Pawła II, asystent sędziego w Sądzie Najwyższym; e-mail: astcjs@sn.pl. 


\section{Ochrona interesów grupy (roszczenia zbiorowe) w jurysdykcji sądów powszechnych oraz Sądu Najwyższego w Polsce}

\section{Streszczenie}

Ustawa z 17.12.2009 r. o dochodzeniu roszczeń w postępowaniu grupowym regulująca postępowanie sądowe $\mathrm{w}$ sprawach, $\mathrm{w}$ których dochodzone są roszczenia co najmniej 10 osób, jest swoistym novum w prawie polskim. Niewątpliwie jest aktem prawnym usprawniającym i unowocześniającym polskie postępowanie cywilne. Jednakże powinno się zwrócić uwagę na nowe rozwiązania i brak ich doprecyzowania, a co za tym idzie znaczenia wydanych już w tych sprawach orzeczeń Sądu Najwyższego. Z tego względu przedstawione i przeanalizowane zostało dotychczasowe orzecznictwo w tym przedmiocie dotyczące dookreślenia zakresu przedmiotowego, pojęcia i zakresu ujednolicenia roszczeń, a także pojęcia i wymogów reprezentanta grupy. Niewątpliwie zaczynająca kształtować się praktyka, co zostało wskazane na przykładzie orzeczeń, pozwoli dopiero doprecyzować zakres przedmiotowy i podmiotowy ustawy. Duże znacznie dla funkcjonowania postępowań grupowych ma możliwość ograniczenia roszczeń do żądania ustalenia odpowiedzialności pozwanego, bo ujednolicenie roszczeń pieniężnych jest w praktyce bardzo trudne. Dotychczasowe orzecznictwo sądów wskazuje, że ujednolicenie należy rozumieć jako wystąpienie przez wszystkich członków grupy z żądaniem udzielenia tej samej rodzajowo formy ochrony prawnej. Wiele problemów praktycznych budzi także pojęcie reprezentanta grupy i sposobu, w jaki grupa powinna dokonać jego wyboru.

Słowa kluczowe: Postępowanie grupowe, reprezentant grupy, ujednolicenie roszczeń, konsument 
$\mathrm{T}$ he Act of 17 December 2009 on pursuing claims in class actions, ${ }^{2}$ (hereinafter referred to as APCCA) regulating court proceedings in cases which involve claims of at least 10 people, is a kind of novelty in Polish law. The course of the legislative process and observation of discussions on the draft law on pursuing claims in class action with the scientific and public consultations shows that this law is a legal act streamlining and modernizing Polish civil proceedings. ${ }^{3}$ This new act does not constitute a comprehensive regulation of class action, but fully regulates all new issues connected with class actions. ${ }^{4}$

The assumption of the legislator was that the legal possibility of bringing a class action in the interests of a group of entities would accelerate and simplify the procedure. When it comes to the functioning of the judicature, critical opinions were expressed repeatedly, especially pointed at the excessive length of proceedings and high fees of their conduction. Also, pursuing claims of small value is uneconomical due to the high (in relation to the claim) fees. Those two obstacles can make court proceedings unattractive, which translates into resignation from the claims.

However, one should pay attention to new developments and the lack of their clarification, and therefore to the importance of already issued judgments of the Supreme Court. The decision to create a separate act has been dictated primarily by the need to verify the functioning of the new legal regulation. If the procedure will work in practice, the legislature does not preclude the inclusion of its provisions to the civil proceedings.

2 Dz.U. (Journal of Law) of 2010, No. 7, item 44.

3 Justification of a Project of the Act on pursuing claims in class actions, see: www.ms.gov.pl//kkpc/ proj080611_uzas.rtf (30.04.2015).

4 See: P. Pogonowski, Postępowanie grupowe - podstawowe założenia teoretyczne na tle istniejących unormowań proceduralnych, [in:] H. Dolecki, K. Flaga-Gieruszyńska (eds.), Ewolucja polskiego postępowania cywilnego wobec przemian politycznych, społecznych i gospodarczych, 2009, p. 45; R. Kulski, Powództwo grupowe w świetle amerykańskiego federalnego prawa procesowego cywilnego, [in:] H. Dolecki, K. Flaga-Gieruszyńska (eds.), Ewolucja polskiego postępowania..., p. 190; Weitz K., Postępowanie w sprawach o uznanie postanowień wzorca umowy za niedozwolone, [in:] T. Wiśniewski (ed.), System prawa handlowego, Postępowanie sądowe w sprawach gospodarczych, 2007, p. 186; M. Sieradzka, Postępowanie grupowe - kolejny krok w kierunku wzmocnienia ochrony interesu wielu podmiotów w jednym postępowaniu, „Przegląd Prawa Handlowego" 2010, 4. 
For this reason, the jurisdiction in this matter needs be analyzed, in order to precise the scope of objectives, define the concept of claim standardization, as well as the concept and requirements of a representative of the group.

\section{The scope of the cases examined in a class action suit in the light of judgments of court}

The basic group of entities, which use the class actions, are consumers who can pursue their claims without fear of high fees. The legislature, in order to ensure the competitiveness of the class actions in relation to ordinary civil proceedings, introduced a lower rate of court fees in cases concerning property rights claimed in the class action. Due to the fact that the practice of class actions is only emerging, the judgments play an important role.

The aim of the class actions is the accumulation of claims of many people who have similar claims as a result of one event in one proceeding. The possibility to combine claims of many entities and joint occurrence against the perpetrator of damages, increase the importance of such proceedings It is also pointed out that proceedings such as these lead to a precedent-setting judgments, to guide the jurisdiction for the future. ${ }^{5}$

The concept of the claim, used both in Art. 1 para. 1 and in the Art. 1 para. 2 APCCA, refers only to substantive claims, rather than procedural. The claims in class actions can concern only a specific benefit (action or lack of action). ${ }^{6}$

Regulation of the Art. 1 para. 2 APCCA determines the narrowing of the scope of possibilities in which the Act can be used. In a class action the following claims may be pursued:

$\square$ claims for consumer protection;

$\square$ claims for liability for the damage caused by dangerous products;

$\square$ claims for tort, with the exception of claims regarding protection of personal rights.

The Act therefore contains, in addition to the admissibility of class action Art. 1 para. 1 of the Act, the limitations of an objective nature (Art. 1 para. 2). ${ }^{7}$

The concept of 'claims for consumer protection' appears in Art. $61 \S 1$ of the Code of Civil Procedure (hereinafter referred to as CCP), defining the scope of activities

\footnotetext{
$5 \quad$ M. Sieradzka, Postępowanie grupowe..., op. cit.

6 M. Lemkowski, Pozwy zbiorowe nie w każdej sprawie, „Rzeczpospolita” 2001, 178.

$7 \quad$ M. Sieradzka, Ustawa o dochodzeniu roszczeń w postępowaniu grupowym. Komentarz, 2010, p. 51.
} 
of social organizations. In order to determine the meaning of claims for consumer protection it will be helpful to refer to the concept of the consumer (Art. 221 of the Civil Code, hereinafter referred to as CC). The consumer is a natural person, who takes legal action not related directly to its business or professional activity. The purpose of the action is very significant, and it does not have the economic aspect. The consumer should also be regarded as a person who, acting as a potential buyer of goods or services, enters into a legal relationship which is in direct relation to the operation of the entrepreneur as a manufacturer or seller of goods or providing services. ${ }^{8}$ Consumer protection cases are matters concerning the claims of consumers against traders arising from different bases. ${ }^{9}$ Cases regarding consumer protection are cases arising from consumer's claim in relation to the entrepreneur, e.g. arising from the contract of lease, contract of sale, contract of loan, or contract of carriage. The Supreme Court in the resolution of seven judges of 29 February $2000,{ }^{10}$ pointed out that cases of consumer protection within the meaning of Art. $61 \S 1 \mathrm{CCP}$ are matters arising from a contract of residential lease, designed to meet the personal housing needs of the tenants if the landlord is an entrepreneur operating in the field of tenancy.

Another type of claims which may also be pursued in a class action are claims for liability for the damage caused by dangerous products. The legislator allows such claims in the class actions. The type of regulation has an important practical dimension as it will allow victims of dangerous products (a group of at least ten people) claim against the entity that has introduced such products.

Liability for dangerous products is regulated by the provisions of the Civil Code (Artt. 4491-44911). Polish legislator in respect of that liability implemented entirely the provisions of Council Directive 85/374/EEC of 25 July 1985 on the approximation of the laws, regulations and administrative provisions of the Member States concerning liability for defective products, ${ }^{11}$ which provides full harmonization in this matter. Liability for dangerous products lies on both producers and distributors on the basis of tort liability. The definition of a hazardous product is contained in Art. $449^{1} \S 3 \mathrm{CC}$, which states that it is a product which does not ensure safety that could be expected, taking into account normal use of the product. The entity authorized in the context of claim for liability for damage to property, which was

8 Decision of the Supreme Court of 15 March 2000, I CKN 1325/99, OSNC 2000, No. 9, item 169, in which the Court pointed out that the case, which concerns the claim of the buyer of goods against the manufacturer or seller, arising in connection with the promotion of goods, is a matter of consumer protection within the meaning of Art. $61 \S 1$ CCP.

9 Flaga-Gieruszyńska K., in: A. Zieliński (ed.), Kodeks postępowania cywilnego. Komentarz, 2008, p. 117.

10 III CZP 26/96, OSN 2000, No. 9, item 152.

11 Council Directive 85/374/EEC, OJ 1985 L 210. 
caused by a dangerous product, is not only the consumer. ${ }^{12}$ In addition to the producer's responsibility Civil Code also foresees the liability of other parties: the manufacturer of the material, raw material or components of the product (Art. $449^{5}$ $\S 1$ CC), the entity claiming to be the manufacturer, importer (Art. $449^{5} \S 2$ CC), a third party or entity, which within its professional activity sells a dangerous product (e.g. vendor, supplier). In a situation where a larger number of entities are responsible for the damage, their liability is solitary (Art. $449^{6} \mathrm{CC}$ ). ${ }^{13}$

In the case of tort claims in class action, there cannot be only one victim of it. The harm must arise in the goods protected by the law of at least ten entities. Cases of claims for consumer protection are only one category of claims that may become the subject of the class action. Other issues mentioned in the Art. 1 para. 2 APCCA do not have to apply to consumers at all. From the context of these rules it can be said without any doubt (at least implicite) that pursuing collective claims is not limited (restricted) subjectively (of course, in this context, the limitations resulting from the provision of Art. 1 or Art. 2 para. 1 APCCA must be taken under consideration) ${ }^{14}$

The legislature expressly excluded from its scope pursuing claims for the protection of personal rights in order to ensure effective pursuing collective claims. In this case the scope of protection is limited to cases of claims for consumer protection, claims for liability for damage caused by dangerous products, and claims for tort, with the exception of claims regarding protection of personal rights. In practice, it will greatly reduce the application of the Act, e.g. by excluding labour claims. ${ }^{15}$

According to the decision of the Court of Appeal in Katowice, ${ }^{16}$ the case filed by a member of a housing cooperative against that housing cooperative in connection with the contract of supplementation of the housing contribution due to the modernization of the building is a matter of a claim for consumer protection within the meaning of Art. 1 para. 2 APCCA. This is a result of the fact that the jurisdiction of the Supreme Court accepted that a housing cooperative is an economic entity

12 See: E. Łętowska, Prawo umów konsumenckich, 2001, p. 127; J. Jagielska, Odpowiedzialność za produkt, "Monitor Prawniczy", 8, 2000.

13 See: M. Sieradzka, Ustawa o dochodzeniu roszczeń..., op. cit., p. 60.

14 Eadem, Postępowanie grupowe - kolejny krok w kierunku wzmocnienia ochrony interesu wielu podmiotów w jednym postępowaniu, „Przegląd Prawa Handlowego” 2010, 4.

15 See: M. Rejdak, Konsumenci wystąpią o odszkodowania w pozwie zbiorowym, „Tygodnik Prawa Gospodarczego Gazety Prawnej" 15.06.2010; idem, Pozwy zbiorowe nie dla roszczeń o ochronę dóbr osobistych, „Tygodnik Prawa Gospodarczego Gazety Prawnej”, 06.07. 2010.

16 Decision of the Court of Appeal in Krakow of 15 October 2013, I ACz 873/13, LEX No. 1381390. 
and in terms of its business aimed at the broadly defined fulfilling of the housing needs of its members must be treated the same way as other entrepreneurs. ${ }^{17}$

As pointed out in one of the judgments of the Regional Court in Lodz, the concept of claim for consumer protection is also to establish contractual liability related to the issue of non-performance or improper performance of obligations within the meaning of Art. 471 CC. In this case, the case will be about improper performance of obligations arising from legal actions in the form of consumer contracts. $^{18}$

In the class action pursue claims for valorisation payment in the development contract has also been approved, as underlined by the decision of the Regional Court in Warsaw. ${ }^{19}$ Claims of the collective are based on the same factual and legal basis. The members of the collective are consumers who have signed their individual contract with the defendant on the basis of the same or a similar model of the contract.

In each of the contracts a valorisation clause was reserved and the impossibility of withdrawal from the contract in case of increase of real estate prices as a result of the valorisation. The fact that the contents of individual clauses are different from each other does not matter. It is also important to point out that the identity of the clauses should not be understood as exactly the same wording. All contracts were written to the same, uniformed pattern. ${ }^{20}$ The Members of the collective have paid undue benefits to the defendant and claimed that the defendant unjustly enriched at their expense. The cause of plaintiffs' impoverishment has the same source - the contracts signed with the defendant, which included prohibited valorisation clauses.

Similarly, in the decision of the Court of Appeal in Warsaw of 8 August 2013, ${ }^{21}$ it is pointed out that when the members of the collective, who are the buyers of the premises, derive their claims directed to the developer from the fact that the contracts included valorisation clauses, which imposed an obligation on the buyers to pay the surcharge to the price of the apartment, there is no doubt that these claims

17 Among others: Resolution of the Supreme Court of 6 December 1991, III CZP 117/91, OSNC 1992, No. 5, item 65, judgment of the Supreme Court of 18 December 1996, I CKN 28/96, OSNC 1997, No. 4, item 44, Resolution of the Supreme Court of 26 April 2002, III CZP 21/02, OSNC 2002, No. 12, item 149, Resolution of the Supreme Court of 11 June 1992, III CZP 64/92, OSNCP 1992, No. 12, item 225, Resolution of the Supreme Court of 14 May 1998, III CZP 12/98, and decision of the Supreme Court of 23 April 1998, II CZ 35/98, UNPUB.

18 Decision of the Regional Court in Lodz of 6 May 2011, II C 1693/10, LEX No. 1499238.

19 Decision of the Regional Court in Warsaw of 24 January 2013, III C 491/12.

20 See: E. Rutkowska, M. Sieradzka, Nieuczciwe praktyki rynkowe stosowane przez banki wobec kredytobiorców-konsumentów. Part I, „Pr. Bankowe” 2008, 2.

21 Decision of the Court of Appeal in Warsaw of 8 August 2013,VI ACz 1639/13, LEX No. 1499167. 
are based on the same factual basis. Moreover, if the members of the collective argue that the benefit paid by them in the form of surcharge is unjustified, since the clauses are of prohibited character in the meaning of Art. $385^{3} \mathrm{CC}$ and thus do not bind the consumers, their claims are based on the same legal basis.

As stated by the Court of Appeal in Warsaw, ${ }^{22}$ diversity of the conditions and models of the contract connecting the members of the collective with the defendant, the mode of contracts - directly from the insurer or agent, performance of the obligation of information in different ways, are not circumstances justifying the approach that the claims cannot be considered to be based on the basis of the same facts. This assessment is also not changed by the differenced in value of the surcharges, nor by the difference in frequency of their payments, or the value of the redemption fee applicable to the individual members of the collective. The claims of the members of the collective are based on the same basis, which is a contractual clause that formed the basis for the defendant to charge the redemption fee, which, according to the members of the collective was grossly exaggerated. In this case all members of the collective pursuing claim, as natural persons and consumers, have signed a life insurance contract with insurance capital funds with the same insurer (defendant), agreed on model contracts created by the defendant, entered into the contracts for the same period of time, or committed to regular payments in the form of insurance premiums to the defendant.

According to the decision of the Supreme Court of 28 January $2015,{ }^{23}$ it is permissible in a class action to raise a complaint to establish the defendant's liability on a pecuniary claim arising from tort resulting from one event (Art. 2, para. 3 in connection with Art. 1, para. 1 and 2 APCCA), also in a situation where the condition of the damage and its amount is dependent on the individual facts relating to the individual members of the collective. With this decision, the Supreme Court has allowed for the identification of a class action lawsuit against the State Treasury represented by the Minister of the Treasury, the General Inspector of Building Control and Mayor C. to establish that the Treasury - Minister of Treasury in connection to Art. $446 \S 3$ and Art. $434 \mathrm{CC}$ is responsible for damages resulting from a significant deterioration in conditions of lives of the plaintiff and other members of the collective, which were caused by the deaths of close family members, as a result of the construction catastrophe of an exhibition pavilion No.1 of International Trade Fair on 28 January 2006, and to establish that the Treasury - General Inspector of Building Control (or District Inspector of Building Control) in connection to Art. $446 \S 3$ and Art. $417 \S 1$ CC bears responsibility towards the plaintiff

\footnotetext{
22 Decision of the Court of Appeal in Warsaw of 6 February 2015, I ACz 43/15, LEX No. 1646028.

23 Decision of the Supreme Court of 28 January 2015, I CSK 533/14, LEX No. 1648177.
} 
and other members of the collective for damages resulting from a significant deterioration in conditions of lives of the plaintiff and other members of the collective, which were caused by the deaths of close family members, as a result the catastrophe that remains at an adequate causal connection with the unlawful omission in the exercise of public authority by the District Inspector of Building Control.

The first judgments on the admissibility of claims in a class action against the banks are of particular importance. This is due to the fact that the main purpose of the class action is to establish the defendant's liability for a specific event, while the conditions of this liability shall be investigated only in individual proceedings. ${ }^{24}$ In the largest, so far, class action in Poland, the group of consumers filed a lawsuit against BRE Bank SA (currently mBank SA). The Mortgage contract included a clause, which entitled the bank to unilaterally change the interest rates. The bank benefited from this clause, and raised interest rates for borrowers during adverse changes in economic parameters. However, when the market situation has changed for the benefit of the consumers, mBank did not lower the interest rates sufficiently. In this way, performed the contracts inadequately, and charged higher interest rates, inter alia, in the period from January 2009 to the end of February 2010. On 6 May 2011, after the hearing, the Regional Court in Lodz issued a decision and found that the case is suitable to be recognized in the class actions. Until 31 March 2012 the group consisted of the total of 1,247 consumers, and on 6 September 2012 the Court issued a decision, which established the final composition of the group. The value of the claim was 5 million PLN. On 30 April 2014 the Court of Appeal in Lodz issued a judgment, which dismissed the bank's appeal and thus upheld the decision of the District Court. ${ }^{25}$ As pointed out in the judgment of the Court of Appeal, basing the claim on the circumstances that all mortgage contracts signed with the bank by the members of the collective included clauses concerning interest rates on loans and equal understanding of these clauses by consumers regarding the mechanism of changes in interest rates on loans and the issue of inadequate performance of contracts by the defendant in relation to the individual members of the collective in terms of changing interest rates on credit, is the basis of the actual lawsuit claim for the bank's contractual liability.

On the hearing which took place on 4 March 2015, the Regional Court in Warsaw issued a decision on the admissibility of the class action initiated by a group lawsuit against, among others, the Treasury and the Social Insurance Institution

\footnotetext{
24 M. Sieradzka, Glosa do postanowienia SN z dnia 28 stycznia 2015 r., I CSK 533/14, LEX/el 2015, No. 257226.

25 Judgment of the Court of Appeal in Lodz of 30 April 2014, I ACa 1209/13, UNPUB.
} 
on establishing the liability of the Treasury resulting from the abolition of the accounting units accumulated on the accounts kept by pension funds. ${ }^{26}$

The Court of Appeal in Warsaw, with the decision of 31 March 2015, ${ }^{27}$ declared admissible the class action in a claim of a limited liability company in Warsaw against the joint stock company in Warsaw for damages arising from the loss of customers and incomes as a result of an advertising campaign carried out by the defendant's company. The advertisements, of which further broadcasting was banned, led to a reduction in customer interest in purchasing insurances through insurance agents, and this had a the direct effect of the loss of income by the members of the collective.

It is clear from the jurisdiction, also between the parties of the process, that the defendant's use of the standard loan contract, as well as the fact of signing credit contracts with consumers within the meaning of Art. 221 CC, is not disputable. This was also confirmed by a final decision on the final determination of the composition of the group. The basis of the dispute is the nature and interpretation of clause on changes in interest rates in the loan contracts, the issue of proper implementation of the contract during the period covered by the lawsuit and its relationship with the defendant's contractual liability, the class action is acceptable. ${ }^{28}$ Proceedings in the abstract control of the clauses used in the standard contracts aim to make the ex-ante eradication of certain provisions contained in the standard contract, understood as a set of clauses and not those of specific contracts. In contrast, the legality of the use of individual clauses in a particular contract is examined only in incidental control mode, taking into account the provisions of the whole contract, the distribution of rights and obligations of the parties. However, by its nature, it should be done at the moment of concluding the agreement, because just from that moment it becomes acceptable.

It has been found acceptable in the jurisdiction that the claim of the representative of the group was defined as a claim for damages on the basis of Art. $417^{1} \S 1$ CC, which claims the responsibility, among others, of local government units for damage caused by an unlawful act or omission in the exercise of public authority - in a particular case where the injury was caused by the release of a normative act on the issue of a resolution by the City Council on payment and conditions for use of

\footnotetext{
26 Decision of the Regional Court in Warsaw of 4 March 2015.

27 Decision of the Court of Appeal in Warsaw of 31 March 2015, I ACz166/15, UNPUB.

28 Judgment of the Court of Appeal in Lodz of 30 April 2014, I ACa 1209/13, UNPUB.
} 
public kindergartens. At the same time the Court of Appeal underlined that any harm is the premise of the admissibility of the claims for tort in class action. ${ }^{29}$

However, class actions cannot be performed in claims for compensation for damage to reputation or for physical injury. Also pursuing claims from the employment relationship does not fall in the scope of the Act, ${ }^{30}$ and therefore employees cannot file a lawsuit against their employer in class action. ${ }^{31}$ But there is a view that in classifying the case, in which the employees derive their rights from ones mentioned in Art. 1 para. 2 APCCA, there are no obstacles to investigate the employees claims against their employer in class action. One must therefore reject the opportunity to qualify matter between the employee and the employer as a matter of consumer protection or liability for damage caused by a dangerous product, but you cannot rule out the possibility of classifying the matter between the employee and the employer as a matter of claim in tort. ${ }^{22}$

A lot of controversy as to the admissibility of filing the lawsuit aroused around a lawsuit against Bank of Food SA (hereinafter referred to as BGZ) on behalf of a group of more than 50 people who were harmed because of the activity of Amber Gold which indicated that BGZ, which was running the bank account of the Amber Gold company, was not diligent in accepting money from clients of Amber Gold. Cooperation with the bank could legitimize, in the eyes of the customers, dishonest business of the entity, the reliability of which has not been duly verified by the bank. Moreover, according to the plaintiff, BGZ should notify law enforcement agencies about suspicious activity of Amber Gold earlier than in May 2012. According to the plaintiff, if BGZ notified the General Inspector of Financial Information or law enforcement authorities before the company lost liquidity, it could protect customers against the loss of savings entrusted with Amber Gold.

As indicated by previous jurisdiction, the class action is becoming popular and the scope of claims pursued expands.

\section{Unification of claims}

Another issue of concern and which demands formation of the practice in this regard is the form and scope of unification of the claims.

\footnotetext{
29 Judgment of the Court of Appeal in Katowice of 18 February 2014, I ACa 1164/13, OSA 2014, No. 12, items 93-111.

30 A. Bobowska, Pracownicy nie wytocza powództw zbiorowych, "Gazeta Prawna" 2009, 245.

31 A. Miśkiewicz, Pozwy grupowe, „Służba Pracownicza” 2012, 6.

32 W. Ostaszewski, Postępowanie grupowe a prawo pracy, PiZS 2011, 2.
} 
Classification of claims can be made in accordance with the doctrine in different ways. Code of Civil Procedure speaks of both pecuniary (Art. 19 § CCP) and non-pecuniary claims, as well as of property (Art. 17, Art. 19 § 2, Art. 33, Art. 187 CCP) and non-property claims (Art. $17 \mathrm{CCP}$ ). In jurisprudence and doctrine, the one of the principal divisions of claims - based on the criterion of legal protection - is their division into claims: for adjudication of benefits, determining and shaping the law or legal relationship. ${ }^{33}$

As it is indicated, the Act also uses criterion of the character of the goods, which are protected and as a result distinguishes property and non-property claims. In this case, the basic of this diversification is the typical interest which is to pursue. Crucial is if the type of the goods, which are the reason for claim, have a property or non-property character. However, any claim based on economic interests will have a property nature. Thus, pecuniary claims have one character, and the non-pecuniary claims arise only when it comes to one type of the behaviour of the defendant, e.g. abandonment of using a specific unfair market practice. Therefore, it cannot be accepted, some people within a certain group request payment of certain sum of money, and other put forward non-pecuniary demands, e.g. refraining from certain behaviour. ${ }^{34}$ The premise of one-type claims under the act is more widely understood than under join actions (Art. $72 \S 1$ pt. 2 CCP) at which it is required to base claims on the same factual and legal basis, contrary to Art. 1 para. 1 APCCA, which puts no such condition..$^{35}$ However, in practice, this means that the judgment in the class action does not have to have an identical content with respect to each member of the collective. ${ }^{36}$

According to the decision of the District Court in Wroclaw, I Civil Division, of 28 January $2014,{ }^{37}$ the members of the collective, represented by the plaintiff, pursue one type of claim, understood, in the sense of the process, as claiming by all its members for generically the same forms of protection, namely the claim for payment. The members of the collective demand awarding them a certain sum of money, performing against a defendant with on type of pecuniary claim. And since they intend to protect the property interest, because of the character of the

33 J. Jodłowski, W. Siedlecki (eds.), Postępowanie cywilne. Część ogólna, 1968, p. 263.

34 M. Rejdak, Jednorodzajowe roszczenia w postępowaniu grupowym, PPH 2010, 8, p. 24.

35 Decision of the Court of Appeal in Lodz of 3 December 2013, I ACz 781/13, UNPUB.

36 M. Rejdak, P. Pietkiewicz, Ustawa o dochodzeniu roszczeń w postępowaniu grupowym. Komentarz (2011), at 252-253, and judgment of the Court of Appeal in Warsaw of 15 April 2014, I ACa 1435/13, <http:// orzeczenia.waw.sa.gov.pl/details/\$N/154500000000503_I_ACa_001435_2013_Uz_2014-0415_001> (20.06. 2015).

37 Decision of the Regional Court in Wroclaw of 28 January 2014, I C 1688/13, UNPUB. 
goods to be protected, it is clear that because of its property character the claim is of one type.

The claims based on the same factual basis are claims are which have their source in the same factual basis (sensu stricto), or claims which share the same factual circumstances (sensu largo). The members of the collective, despite the fact that each of them had individual contracts concluded with the defendant company, may rely e.g. on the abusive nature of the contractual clauses functioning in the model contracts applied for each client. Therefore, in this sense, it is the same factual basis, and individual differences arising from the content of individual legal relationships of the members of the collective do not result in 'separation' of the factual basis of their claims. The same factual basis of the claims (identity of the facts) exists when between the members of the collective a bond is presented based on the unity of the event giving rise to the claim. The claims of each member are derived not so much from the individual contracts, but from the fact that each of them according to allegations contained in the lawsuit - contained a regulation which determined the way of calculation the surface of the premises for the purposes of determining the price which, according to the members of the collective, had a nature of abusive clause.

The rules for standardization of the claims of the members of the collective and establishment of sub-groups relied on the comparison of claims of the individual members or the groups in such a way that the nominally lowest value of the claims of a member (members) of the collective is accompanied by a claim of another member (members) of the collective of nominally next value. At the same time, the lawsuit had a table attached, which set out the claims of the members of the collective broken down by subgroups, indicating the member (members) of the collective and entitlement claims, broken down into subgroups and indicating the claims and unifying claims within subgroups.

As clarified by the decision of the Court of Appeal in Gdansk in the decision of 14 May 2013, ${ }^{38}$ joint circumstances of the case, within the meaning of Art. 2 APCCA, which admit the unification of the claims in the context of created subgroups, are circumstances that are common, which means that they are the same for the members of the collective, and at the same time different from those which were decisive in terms of isolating other subgroups. In a situation where the factual and legal basis for the claims and their unified character are the same for all the plaintiffs, the standardization of claims, if the plaintiffs decide to proceed with a class action, must be done in relation to all of them, without the possibility of dividing into smaller groups, conditioned only by different value of the same claim. In contrast,

38 Decision of the Court of Appeal in Gdansk of 14 May 2013, V ACz 354/13, UNPUB. 
diversity of the conditions of the contracts and patterns connecting the members with the defendant, the procedures for the conclusion of the contract - directly from the insurer or the agent, performing the duty of information in different ways, are not circumstances justifying the view that the claims cannot be considered as based on the same factual basis. This assessment is also not changed by the difference in the amount of insurance premiums and frequency of their payments, or the amount of the redemption fees applicable to the individual members of the collective. The members of the collective form their claims basing on the same contractual clause, which allowed the defendant to charge redemption fees, which, according to the members of the collective were grossly excessive. ${ }^{39}$

\section{The representative of the group and its attributes}

In class action specific rules considering the representation of the group (subgroup) were introduced, arising many difficulties and doubts mainly as to the compulsory services of attorneys and the nature of the bond between a representative of the group and its members. By introducing the institution of a class action representative in the legislator was guided by, firstly, the need to introduce adequate protection of the interests of many entities in one set of proceedings, secondly, the need to ensure professional and effective representation. Those were the main reasons for creating the institution of a representative of the group in class actions. From subjective point of view of, the representative of the group may be a member of the group, or district (municipal) consumer advocate in terms of its prerogatives. ${ }^{40}$ The representative a party - the plaintiff in the sense of the process. It is responsible to the group for meeting the deadlines, for the contents of the contract with the attorney or, for example, by regulating relations between the members of the collective in case of a situation when individuals leave the group. It is also responsible for regulating the internal settlement between group members, and concerning for example the matter of bail, the consequences of refraining from its paying, obligation to pay the legal costs associated for example with the press release announcement. ${ }^{41}$

It is important to state that all members of the collective must agree to represent their interests in the proceedings by the representative of the group. The respon-

\footnotetext{
39 Decision of the Court of Appeal in Warsaw of 6 February 2015, I ACz 43/15, LEX No. 1646028.

40 Decision of the Regional Court in Lodz of 6 May 2011, 1693/10, UNPUB, and judgment of the Regional Court in Lodz of 3 July 2013, UNPUB.

41 See: Budzowska J., Pozwy zbiorowe - co przepis to wątpliwość, „Rzeczpospolita” PCD, 9 July 2010.
} 
sibilities of the representative of the group have been defined by law and determined by the contract with the members of the collective. In contrast, the relationship between the members of the collective and the representative can be described as indirect replacement. It should be noted that the group representative is not the legal representative in the case. As rightly pointed out by the Supreme Court in one of its resolutions, the representative of the group in the case has a position of a party. ${ }^{42}$ Participation in the case action of district (municipal) consumer advocate is based on the principle of subrogation. The doctrine emphasizes that this is a case of subrogation process, which, as the first in the Polish procedure, is anchored in statements of intention of the members of the collective, not in the act. ${ }^{43}$

The principles of the representation of the group in a class action have been already clarified by jurisdiction on this subject.

Art. 4 para. 1 and 3 APCCA indicate that the class action suit filed by the representative of the group conducting an investigation in its own name, but on behalf of all members of the collective. Furthermore, according to Art. 21 para. 1 APCCA in the operative part of the judgment all the members of the collective or subgroup should be mentioned. Therefore, overlooking all members of the collective in the operative part is impossible. ${ }^{4}$

According to the decision of the Court of Appeal in Warsaw, ${ }^{45}$ an entity can be or cannot be entitled to judicial capacity and it is not divisible. Moreover, its capability is not a subject related to the territorial scope of the competence of a particular entity. A district (municipal) consumer advocate is entitled to judicial capacity also when the group will be by people from outside of the area of its operations. Since the district (municipal) consumer advocate may be the representative of the group, it is thus entitled to conclude the contract referred to in Art. 6 para. 2 APCCA. A case can be recognized under the Act of 2009 on pursuing claims in class actions when: firstly, the claims are of the same kind, e.g. pecuniary claims, secondly, the claims are of at least 10 people, and thirdly they are based on the same factual

42 T. Jaworski, P. Radzimierski, Ustawa o dochodzeniu roszczeń w postępowaniu grupowym. Komentarz (2010), at 158-159; M. Sieradzka, Ustawa o dochodzeniu roszczeń w postępowaniu grupowym. Komentarz (2010), p. 135-137; P. Grzegorczyk, Ustawa o dochodzeniu roszczeń w postępowaniu grupowym. Ogólna charakterystyka (2011), p. 59.

43 T. Jaworski, P. Radzimierski, Ustawa o dochodzeniu roszczeń..., op. cit., p. 147. There is also a view that the legitimacy of the consumer advocate is a rather special legitimacy, which does not have a personal nature, because the right to be the plaintiff has no material relationship with the private claims that are asserted in a class action - see: M. Rejdak [in:] M. Rejdak, P. Pietkiewicz, Ustawa o dochodzeniu roszczeń..., op. cit., p. 112.

44 Judgment of the Court of Appeal in Gdansk of 30 October 2013, I ACa 471/13 (I ACz 869/13), UNPUB.

45 Decision of the Court of Appeal in Warsaw of 6 February 2015, I ACz 43/15, LEX No. 1646028. 
basis. Formulating the same factual basis must be understood as basing claims on similar events, which correspond to the concept of equal factual basis, which is part of the formal participation.

As pointed out in the judgment of the Court of Appeal in Lodz of 30 April 2014, ${ }^{46}$ a representative of the group is a key figure in the class action. It was he who brings an action, conducts the proceedings in its own name, on behalf of all members, negotiates and concludes the contract with the legal representative on behalf of the members of the group and gives him the power of attorney. In cases for non-pecuniary claims even execution of awarded benefits for the first six months shall be instituted only at the request of the representative of the group. According to the Art. 4 para. 1 APCCA, class action suit is filed by a representative of the group. So it is the representative of the group who filed a class action for the benefit of the members of the collective, who is the party in the sense of the process. In contrast, the members of the collective, on behalf of whom the group representative filed the suit, are the parties in a material sense. ${ }^{47}$

The resolutions of the Supreme Court of 12 July $2011^{48}$ had a significant meaning for the proper functioning of an institution of a representative of the group. In this resolution the Supreme Court pointed out that the compulsory representation of a plaintiff by a lawyer or legal adviser, stated in Art. 4 para. 4 APCCA also apply to the district (municipal) consumer advocate, who is a representative of the group, and the class action lawsuit, filed without compulsory representation of a plaintiff by a lawyer or legal adviser stated in art. 4 para. 4 APCCA, is rejected without summoning for correction of formal defects. ${ }^{49}$ The Supreme Court clearly stated that the legislator has introduced compulsory representation of a plaintiff by a lawyer or legal adviser, regardless of who is the plaintiff. The only circumstance to exclude this compulsion is a situation where the plaintiff is a lawyer or legal advisor. Thus, if the district (municipal) consumer advocate is a legal advisor, it has the postulation ability. ${ }^{50}$

As stated by the Regional Court in Lodz, ${ }^{51}$ in the case of judicial capacities, the basis for locus standi of the representative of the group is a provision of an act, which does condition the possession of those qualities on the fulfilment of additional, unspecified criteria. This also applies to a consumer advocate, who as a represent-

\footnotetext{
46 Judgment of the Court of Appeal in Lodz of 30 April 2014, I ACa 1209/13, UNPUB.

47 Judgment of the Court of Appeal in Bialystok of 2 October 2013, I ACa 386/13, UNPUB.

48 Resolution fo the Supreme Court of 13 July 2011, III CZP 28/11, OSNC 2012, No. 1, item 9.

49 Sieradzka M., Glosa do uchwaty SN z dnia 13 lipca 2011 r., III CZP 28/11, 7 M.Prawn. (2014), p. 377.

$50 \quad$ Ibidem, p. 378.

51 Decision of the Regional Court in Lodz of 6 May 2011, II C 1693/10, LEX No. 1499238.
} 
ative of the group has legal standing and standing to take legal action to protect consumers in class action arising directly from Art. 4 para. 1-3 APCCA. In contrast, the premise of one-type claims must be interpreted in a way that the claims arising from them are the same to all members of the group. The issue of the actual relationship that occurs between claims must take into account, how it is understood on the basis of the institution of substantive and formal participation in the light of Art. 72 CCP. However, the factual basis for the claim is, on its self, the basic set of facts justifying the claim. The same factual basis for the claim takes place when obtaining legal protection is associated with an identical situation or event. In contrast, the same factual basis is, when claims are only derived from similar situations and events, which correspond to the concept of the same factual basis as an element of formal participation.

\section{Examination of the admissibility of class actions}

Many doubts were also expressed about the complex nature of the proceedings because of a procedure of examination of the admissibility of class actions. Art. 10 para. 1 APCCA indicates that the filing of a class action lawsuit, the court will decide at the hearing on admissibility of class action, which is in some sense an unusual solution, because usually the court examines the admissibility of a proceeding in that matter before appointing the date of the first hearing, limited only to formal issues. ${ }^{52}$ After the examination, the court may order to reject the lawsuit, if the matter cannot be examined in the class action, or issue an order to adjudicate the class action. However, it is not clear enough what is the scope of the court's examination, e.g. if while deciding on the admissibility of class actions, it examines only formal issues, or does it take into consideration the material circumstances as well. The first solution is supported by the wording of Art. 10 para. 1, which provides that the court may reject the lawsuit if there is no basis to hear the case in the class action. The Court must therefore limit its examination only to verify, for example, such matters as whether a class action lawsuit is filed by a group consisting of enough number of people, whether the claim meets the requirements specified in Art. 6 APCCA, whether it has been properly paid, or whether the requirement for representation by a professional attorney was preserved. ${ }^{53}$ Nevertheless, some doubts are raised, that if the court at the hearing decides on the matter indicated above, it is therefore a necessity that it should also assess the physical aspects of

\footnotetext{
52 M. Sieradzka, Ustawa o dochodzeniu roszczeń..., op. cit., p. 179.

53 T. Jaworski, P. Radzimierski, Ustawa o dochodzeniu roszczeń..., op. cit., p. 232.
} 
the lawsuit and take them into account when making a decision on rejecting the lawsuit or on its admission for further proceedings. Yet, it is possible that the court, after admitting a class action lawsuit, will have to dismiss it later on due to the lack of grounds for further proceedings. The fulfilment of the requirements for group members in Art. 1 APCCA, which have, by their nature, a pecuniary character, is of such importance for the further conduct of the class action that it should be taken into consideration at the stage of preliminary examination of a lawsuit already. Due to the economics of the process and the accuracy of court's decisions, the court, while deciding on the admissibility of a class action lawsuit, should also examine it in terms of both: formal and material aspects. The decisive factor in this respect will be the practice adopted by the courts.

In the event of issuing a court decision concerning admission of a class action lawsuit, the party which is dissatisfied with this decision may file a complaint against this decision. The law on class actions does not expressly provide the possibility of submitting a complaint against a decision to reject a class action lawsuit; however, due to the fact that such decision is a judgment closing the proceedings, filing complaints in such case is admissible pursuant to art. $394 \S 1$ CCP.

The Art. 10 para. 3 APCCA shows that in case of rejection of a class action lawsuit by the court, a member of the collective can bring an individual action, pursuing claims filed previously in a collective lawsuit. ${ }^{54}$ If it is done within 6 months from the date of the final decision on rejecting of the lawsuit, then the results of filing the class action lawsuit are preserved in relation to its individual claims, which may be important primarily because of the interruption of limitation period, which occurred on filing a class action lawsuit in court. The establishment of such rule is definitely beneficial for people who have unsuccessfully tried to pursue their claims in a class action. With the introduction of the act, the members of the collective will not have to be afraid that if the class action fails, they will lose their chance to pursue their claims individually.

As pointed out in the decision of the Court of Appeal in Warsaw of 31 March 2015 , the examination of admissibility of class actions is formal and may not be preceded by the examination of validity of the claims. ${ }^{55}$ The basis of the actual matter of the claim is a set of facts justifying the claims of the plaintiff - this basis should include the facts primarily justifying the legal relations which are the matter of the lawsuit. To substantiate the unity of the factual basis it was enough to indicate

\footnotetext{
54 M. Sieradzka, Ustawa o dochodzeniu roszczeń..., op. cit., p. 181.

55 Decision of the Court of Appeal in Warsaw of 31 March 2015, I ACz 166/15, UNPUB; decision of the Regional Court in Szczecin of 9 July 2013, I C 762/12, UNPUB.
} 
the event in the form of broadcasting an advertisement, recognized then by another court for an act of unfair competition.

However, in the decision of the Court of Appeal in Krakow of 10 December 2013, ${ }^{56}$ it was noted that at the stage of determining the composition of the group, the court does not examine the merits of the conditions for tortuous liability of individual defendants and the scope of that liability. The requirement to demonstrate (in cases of pecuniary claims), or prima facie evidence (in other cases, including a case of establishing the belonging to the group) is not identical to the requirement of proving the claims in terms of content, which takes place only within the framework of the examination proceedings.

In its decision of 13 June $2014,{ }^{57}$ the Supreme Court pointed out that the admissibility of the examination of the case in the class action is decided basing on precisely defined in the Act reasons, among which, the desirability of consideration of the case in the class action, is not mentioned.

According to the decision of the Court of Appeal in Katowice of 4 July 2014, ${ }^{58}$ it is not the Court, at the preliminary stage of the case, who prejudges any substantive premises of the claims, but the aim of the Act is so that any possible judgment concerned all members of the collective in the same way, in other words, a situation of admitting the claims of one part of the members of the collective and dismissing the claims in relation to the rest of the members of collective cannot occur. It is only possible to differentiate the amount of awarded benefits. The identity of the legal basis should be of such kind, so that the court was able to assess the claims of all members of the collective.

From the cited jurisdiction results a need to distinguish between admissibility of the class action and examination of substantive facts.

\section{The status of the member of the collective}

In relation to the fact that in the class action pursued claims are of one type, cover claims of at least 10 people, and are based on the same factual basis, it is important to determine the interpretation of the term "collective", as well as the status of its individual members. The collective is created by people, in respect of whom the amount claimed is unified, taking into account the common circumstances of the

\footnotetext{
56 Decision of the Court of Appeal in Krakow of 10 December 2013, I ACz 2189/13, UNPUB.

57 I CSK 654/13, LEX No. 1652710.

58 Decision of the Court of Appeal in Katowice fo 4 July 2014, I ACz 260/14, UNPUB.
} 
case. ${ }^{59}$ Many aspects regarding the status of the member of the collective, the shaping of its composition and making statements were clarified in courts' jurisdiction.

The member of the collective is generally a passive entity in the process. Along with the submission of the declaration to join the collective, his/hers activity in the context of the class action finishes. The member of the collective is not a plaintiff in the sense of the process. Consequently, no rights of a party are entitled to the member in the process. The members of the collective are plaintiffs only in the material sense. However, in a formal sense, the plaintiff is the representative of the group acting in a process on the principle of subrogation resulting from the legislation. ${ }^{60}$

The purpose of creating the institution of the representative was only to allow the courts smooth conduct of the proceedings even in a case, when the group has several thousand of members. Such an assumption should always be guided by the courts adjudicating on the basis of the law, when it comes to a decision on the procedural rights of a group of members during the proceedings. The exclusion of the members from the process of civil proceedings by granting locus standi only to the representative was aimed at improving the legal proceedings. Therefore, the idea was not to take away the procedural rights of the party of the process from the members of the collective. The members of the collective should therefore keep - taking into account the specifics resulting from the class action - the widest range of procedural rights associated with being a party to the proceedings in the material sense.

In the light of the Act on pursuing claims in class actions, an inconsistent approach of the courts in defining the plaintiff can be observed. An example of this is a written mentioning of the members of the collective in the content of procedural decisions other than the judgment. In the event of proceedings, in which the collective is very large, the courts in their decisions, which state the plaintiff, cite only the representative of the collective, ${ }^{61}$ without naming the members of the collective. In cases where the size of the collective is relatively small, at least at the initial stage of the proceeding, the courts also mention, apart from the representative of the collective, the members of the collective who are a part of it on the day of the decision. ${ }^{62}$

59 M. Sieradzka, Postępowanie grupowe - kolejny krok w kierunku wzmocnienia ochrony interesu wielu podmiotów w jednym postępowaniu, „Przegląd Prawa Handlowego” 2010, 4, p. 12.

60 Judgment of the Regional Court in Lodz of 3 July 2013, UNPUB.

61 Decision of the Regional Court in Lodz of 6 May 2011, II C 1693/10, concerning the admission of the case dealt with in a class action in which as the plaintiff is indicated only the representative of the collective (which included, on 6 May 2011 867, consumers).

62 Decision of the Regional Court in Warsaw of 27 June 2013, III C 976/12, concerning the rectification ex officio setting the plaintiff's by mentioning, apart from the representative, also the members of the collective. 
The members of the collective - persons directly interested in the outcome of the case - are in a class action basically deprived of all rights traditionally accorded to the party of the process. These individuals, by joining the collective, entrust its powers to the representative and are related to the consequences of his actions. The members of the collective occupy the position of the party in the material sense and do not participate in the proceedings as a multi-entity party in the process.

As pointed out in the judgment of the Court of Appeal in Lodz of 30 April 2014, exclusive legitimacy to act on behalf of the collective, but in its own name is the representative of the collective, same as a trustee or liquidator after the bankruptcy. Substitution in the process is final. The member of the collective cannot 'join' the case as a plaintiff, gaining thereby procedural position of the party in terms of the process. In the proceedings the members of the collective are entitled to some 'incidental powers' only, in particular to testify as a party, conduct executions of pecuniary benefits awarded to the member of the collective, to issue writ of execution and to conduct executions of non-pecuniary benefits in the event of inaction of the representative. As part of these 'incidental powers' the legislation has not granted the special status of the members of the collective regarding the entitlement to claim reimbursement of the incurred costs of the class action. For the same reason the legislature did not provide for the possibility of charging the individual members of the collective with the cost of the process. Filing pleadings by individual members of the collective is not acceptable in the class action, which does not allow for the treatment of individual group members as participants in the proceedings within the meaning of Art. 7 para. 1 of the Act of 28 July 2005 on court fees in civil cases. ${ }^{63}$ Also, a representative of the collective is obliged to settle the cautio judicatum solvi under the conditions specified in Art. 8 APCCA. Funding of legal costs, like commission salaries of the attorney (Art. 5 APCCA) in the course of the class action remains the domain of intra-group arrangements. It is obvious that the members of the collective can incur expenditures for this purpose, but the law does not interfere in the internal relations of the collective in this regard. ${ }^{64}$

In the light of the jurisdiction on class actions, it is important that the courts exercising jurisdiction under the Act, take into account as much as possible the fact that the members of the collective are substantive party of the class action and the institution of the representative, which is the party of the process in a formal sense, was set up exclusively for improving the procedure and should not affect the limitation of procedural rights of the members of the collective. Freedom to join the group and the presence in it is not, in principle, limited in any way. The

63 Dz.U. (Journal of Law) of 2005, No. 167, item 1398.

64 Judgment of the Court of Appeal in Lodz of 30 April 2014, I ACa 1209/13, UNPUB. 
only obligation which is in this area enforced by the law, is submitting a written declaration stating the joining to the group and agreeing to a person who represents the collective. ${ }^{65}$ Stated in Art. 12 APCCA formal requirements of membership of the collective shall also apply to persons who originally join the group. ${ }^{66}$ Failure by one of the members of the collective, of submitting the declaration does not lead to the inadmissibility of the class action in respect of all the members of the collective because of not fulfilling a condition of one-type claims. The court should take this circumstance into account in order to establish the composition of the collective (Art. 17 para. 1) without placing that person in the composition of the collective. ${ }^{67}$ In accordance with Art. 17 para. 3 APCCA, a statement of the member to withdraw from the group is ineffective if it is filed after the above-mentioned decision came into force. Between the date of filing a lawsuit and the deadline set by the court to join the collective, in practice, always runs at least several months. At this time, the size of the collective may increase significantly. ${ }^{68}$ However, the court's decision on the composition of the collective has a constitutive character, and it is not a statement of a specific person to join the group, but only the court decision on the composition of the group eventually form the collective in a class action. Taking into account the constitutive nature of the provisions regarding the composition of the collective, it can be considered that after a final decision regarding the composition of the collective, the court does not examine whether a group member has the status of a party in the material sense as a rule. However, one must point out that no provision of the Act on pursuing claims in class actions provides, that after a final decision on the composition of the collective, the court could not examine the material legitimacy of the member. ${ }^{69}$

As stated in the decision of the Court of Appeal in Lodz of 3 December 2013,70 it is possible in the class action to have multiple entities as the defendants. Nor the objectives of the Act or its specific provisions stand in opposition to such interpretation. In the case of multiple entities as the defendants, the provisions of the Civil Procedure Code about co-participation are in action, and as an example in class action, co-liable tort claims are mentioned.

\footnotetext{
65 M. Sieradzka, Ustawa o dochodzeniu roszczeń..., op. cit., p. 189.

66 Decision of the Court of Appeal in Gdansk of 14 May 2013, I ACz 464/13, UNPUB.

67 Decision of the Supreme Court of 28 January 2015, I CSK 533/14, LEX No. 1648177.

68 E.g. the class action in the Regional Court in Lodz initiated by the Municipal Consumer Advocate against BRE Bank SA, II C 1693/1610.

69 Judgment of the Court of Appeal in Bialystok of 2 October 2013, I ACa 386/13, UNPUB.

70 Decision of the Court of Appeal in Lodz of 3 December 2013, I ACz 781/13, UNPUB.
} 


\section{Summary}

Undoubtedly, the practice which is starting to shape, as indicated on the examples of jurisdiction, will only clarify the scope of the subjects and objects of the Act. Significant to the functioning of the class actions is the ability to limit the claims for determining the liability of the defendant, because the unification of pecuniary claims is in practice very difficult. Many doubts are raised by the exclusion of the admissibility of the investigation in this proceeding, claims with regard to the protection of personal rights, because, according to the original assumptions of the law on class actions, this Act should involve an unlimited range of issues. It was especially hoped that the class action lawsuits will be an effective means of defending the rights of entrepreneurs which are violated in matters related to the purchase of foreign currency options. It was also assumed that class actions prove themselves in labour matters, in which employees affected by large retail chains would create a collective to pursue claims from dishonest employers. However, in the course of work, it was assumed that the of a class action lawsuit is possible only in cases of claims for the protection of consumers in respect of liability for damage caused by a dangerous product, and tort with the exception of claims for protection of personal rights. Excluding from the scope of class action cases labour claims should be assessed negatively because, as it seems, these matters would be a very large group of issues, which would be raised in this kind of proceedings, and grant employees such powers would definitely impact on improving their procedural situation.

According to the art. 2 para. 1 APCCA, in the case of pecuniary claims, the claims of each victim included in the collective will have to be standardized. This necessitates the unification of the claims in such way that each of the victims may accrue the amount of compensation which would be of a lesser value than originally requested by him. However, the lack of such unification of the claims would call into question the sense of the class action, as the court would have to examine in detail the case of each victim individually to determine the actual value of his claim, which it may do as well in the individual proceedings. The Court, therefore, examines the circumstances of the case, also in relation to all members of the collective, which results in the fact that the proceedings can be conducted faster and more efficiently. Unification of the amount of claims of individual members of the collective means that the amount awarded in their favour in the judgment which closes the class action will just reply to the unified value of the claim and will not be varied for each member of the collective. Past court decisions show that unification should be understood as occurrence of a members' request for the generically same forms of protection. 
The representative of the collective may be its member or district (municipal) consumer protection spokesman. The law does not indicate how the group should choose a representative, leaving the matter to the victims, but it should be noted that the person who is the representative should be accepted by all members of the collective. Art. 6 para. 2 APCCA shows that the class action should be accompanied by, among others, the statement of a member of the collective to join the group and agreeing on the representative. In the explanatory memorandum to the draft of the Act on pursuing claims in class actions it has been pointed out in this regard that relations between members of the collective and its representative may be optionally regulated in a contract. In this contract, the parties may therefore forge mutual rights and obligations as well as predict that a representative of the collective will be paid for its activities. But it is not entirely clear what is the nature of the relationship between the representative of the collective and its members. It is not the power of attorney, as the representative of the collective is not fixating by its members to carry out legal actions on their behalf, especially since the establishment of the representative of the collective is mainly meant to improve the conduction of the proceedings.

Many practical problems are also created during the first phase of the proceedings, which is connected to the examination of admissibility of the case. Attention is paid to the time-consumption of that first, formal stage of the class action, under which courts take three basic decisions, i.e. a decision on admissibility of the case in class action, a decision as to the composition of the group, a decision considering the deposit, unless the defendant submits such a request.

Hence the jurisdiction on this subject will be shape by the actual practice and extensive use of this procedure.

\section{References}

Bobowska A., Pracownicy nie wytocza powództw zbiorowych, "Gazeta Prawna” 2009, 245. Budzowska J., Pozwy zbiorowe - co przepis to wątpliwość, "Rzeczpospolita” PCD, 9.07. 2010. Flaga-Gieruszyńska K., in: A. Zieliński (ed.), Kodeks postępowania cywilnego. Komentarz, 2008.

Grzegorczyk P., Ustawa o dochodzeniu roszczeń w postępowaniu grupowym. Ogólna charakterystyka, 2011.

Jagielska J., Odpowiedzialność za produkt, „Monitor Prawniczy”, 8, 2000.

Jaworski T., Radzimierski P., Ustawa o dochodzeniu roszczeń w postępowaniu grupowym. Komentarz, 2010.

Jodłowski J., Siedlecki W. (eds.), Postępowanie cywilne. Część ogólna, 1968. 
Lemkowski M., Pozwy zbiorowe nie w każdej sprawie, „Rzeczpospolita” 2001, 178.

Kulski R., Powództwo grupowe w świetle amerykańskiego federalnego prawa procesowego cywilnego, [in] H. Dolecki, K. Flaga-Gieruszyńska (eds.), Ewolucja polskiego postępowania cywilnego wobec przemian politycznych, spotecznych i gospodarczych, 2009.

Łętowska E., Prawo umów konsumenckich, 2001.

Miśkiewicz A., Pozwy grupowe, „Służba Pracownicza” 2012, 17.

Ostaszewski W., Postępowanie grupowe a prawo pracy, PiZS 2011, 2.

Pogonowski P., Postępowanie grupowe - podstawowe założenia teoretyczne na tle istniejących unormowań proceduralnych, [in:] H. Dolecki, K. Flaga-Gieruszyńska (eds.), Ewolucja polskiego postępowania cywilnego wobec przemian politycznych, społecznych i gospodarczych, 2009.

Rejdak M., Jednorodzajowe roszczenia w postępowaniu grupowym, PPH 2010, 24.

Rejdak M., Konsumenci wystapiq o odszkodowania w pozwie zbiorowym, „Tygodnik Prawa Gospodarczego Gazety Prawnej", 15.06.2010.

Rejdak M., Pozwy zbiorowe nie dla roszczeń o ochronę dóbr osobistych, „Tygodnik Prawa Gospodarczego Gazety Prawnej", 6.07.2010.

Rejdak M., Pietkiewicz P., Ustawa o dochodzeniu roszczeń w postępowaniu grupowym. Komentarz, 2011.

Rutkowska E., Sieradzka M., Nieuczciwe praktyki rynkowe stosowane przez banki wobec kredytobiorców-konsumentów. Part I, „Pr. Bankowe” 2008, 2.

Sieradzka M., Postępowanie grupowe - kolejny krok w kierunku wzmocnienia ochrony interesu wielu podmiotów w jednym postępowaniu, „Przegląd Prawa Handlowego” 2010, 4.

Sieradzka M., Glosa do postanowienia SN z dnia 28 stycznia 2015 r., I CSK 533/14, LEX/el 2015, No. 257226.

Sieradzka M., Glosa do uchwaty SN z dnia 13 lipca 2011 r., III CZP 28/11, 7 M.Prawn. (2014). Sieradzka M., Ustawa o dochodzeniu roszczeń w postępowaniu grupowym. Komentarz, 2010. Weitz K., Postępowanie w sprawach o uznanie postanowień wzorca umowy za niedozwolone, [in:] T. Wiśniewski (ed.), System prawa handlowego, Postępowanie sadowe w sprawach gospodarczych, 2007. 